\title{
PENGARUH PENAMBAHAN AGAR DAN PATI TERHADAP KARAKTERISTIK CASSAVA LEAF SHEET
}

\author{
Zulfah Maharani $^{1)}$, Anastasia Isnaeni $^{2)}$, Umi Fitriani $^{3)}$, Iffah Muflihati $^{4)}$, Arief R. Affandi ${ }^{5)}$ \\ Fakultas Teknik dan Informatika, Jurusan Teknologi Pangan, Universitas PGRI Semarang, Jl. Sidodadi \\ Timur N0.24 Semarang Jawa Tengah, Telp (024) 8316377,Email : zulfahmaharani@gmail.com
}

\begin{abstract}
Abstrak
Cassava leaf sheet merupakan produk berbentuk lembaran tipis yang terbuat dari daun singkong dan hampir menyerupai nori. Penelitian ini bertujuan untuk mengetahui pengaruh penambahan agar dan pati terhadap karakteristik cassava leaf sheet. Penelitian ini menggunakan rancangan acak lengkap dengan Perlakuan terdiri dari penambahan bahan pembentuk gel yaitu agar dan pati. Konsentrasi agar yang ditambahkan yaitu ( $1 \%, 2 \%$ dan $3 \%)$ dan pati $(7 \%, 8 \%$ dan $9 \%)$. Analisis yang dilakukan meliputi kadar air, kadar serat kasar, kadar abu dan uji organoleptik. Hasil penelitian didapatkan bahwa perlakuan agar $2 \%$ adalah perlakuan terbaik dengan kadar air 9, 072\%, kadar abu 33,52\%, dan kadar serat kasar yang tinggi dengan karakteristik warna hijau agak gelap, aroma daun singkong yang sedikit kuat, rasa yang agak gurih, rasa yang asin, agak rapuh, dan tidak elastis.
\end{abstract}

Kata kunci: agar, cassava leaf sheet, pati

\begin{abstract}
Cassava leaf sheet is a thin sheet product made from cassava leaves and almost like nori. This study aims to determine the effect of agar addition and starch on the characteristics of cassava leaf sheets. This study used a completely randomized design with treatment consisting of the addition of gelling agents namely agar and starch. Order concentrations were added (1\%, 2\% and 3\%) and starch (7\%, $8 \%$ and $9 \%)$. The analysis carried out included water content, crude fiber content, ash content and organoleptic test. The results showed that the treatment of $2 \%$ was the best treatment with water content $9,072 \%, 33.52 \%$ ash content, and high crude fiber content with a rather dark green characteristic, the aroma of cassava leaves was slightly strong, the taste was rather savory, the taste is salty, somewhat brittle, and not elastic.

Keywords: agar, cassava leaf sheet, starch
\end{abstract}

\section{PENDAHULUAN}

Daun singkong sudah banyak dikenal masyarakat kita sejak dahulu sebagai sayuran alternatif pengganti dari kebanyakan sayuran pada umumnya.Kandungan serat dan mineralnya rata-rata lebih tinggi dibandingkan dengan sayuran daun lain.Kandungan kalsium yang tinggi sangat baik untuk mencegah penyakit tulang seperti rematik dan asam urat (Adi, 2006).

Dikarenakan proses pengolahan daun singkong yang masih terbatas dan didukung banyaknya kandungan gizi pada daun singkong, maka dilakukan suatu diversifikasi produk pangan yaitu cassava leaf sheet. Cassava leaf sheet merupakan produk berbentuk lembaran tipis yang terbuat dari daun singkong dan hampir menyerupai nori. Menurut Giury (2006), nori adalah salah satu produk olahan rumput laut yang dikeringkan. Cassava leaf sheet ini dapat dimakan langsung sebagai camilan ataupun sebagai penyalut (coating).

Pada pembuatan cassava leaf sheet diperlukan bahan pembentuk gel dikarenakan nori yang terbuat dari rumput laut terdapat zat pembentuk gel sendiri dari rumput laut tersebut, sehingga pembuatan cassava leaf 
sheet diperlukan zat pembentuk gel yang serupa dengan rumput laut yaitu berasal dari pati. Bahan pembentuk gel dapat memberikan bentuk atau rangka pada produk cassava leaf sheet dan dapat memperkokoh bentuk lembaran sehingga tidak mudah rusakdan robek dan dapat mempengaruhi karakteristik produk.

Beberapa bahan penstabil dan pengental juga termasuk dalam kelompok bahan pembentuk gel. Jenis-jenis bahan pembentuk gel biasanya merupakan bahan berbasis polisakarida atau protein. Contoh-contoh dari bahan pembentuk gel antara lain asam alginat, sodium alginat, kalium alginat, kalsium alginat, agar, karagenan, locust bean gum, pektin dan gelatin (Raton and Smooley, 1993). Sehingga dalam penelitian ini menggunakan bahan pembentuk gel pati dan agar dalam pembuatan cassava leaf sheet.

\section{METODE PENELITIAN Bahan}

Bahan utama yang digunakan dalam penelitian ini yaitu daun singkong. Bahan lain yaitu agar, pati (tepung kanji), garam, lada, bawang putih, air dan minyak wijen. Bahan yang digunakan untuk analisis yaitu $\mathrm{H}_{2} \mathrm{SO}_{4}$, aquades, alkohol 95\% dan $\mathrm{NaOH}$.

\section{Rancangan Penelitian}

Penelitian ini menggunakan Rancangan Acak Lengkap (RAL) 2 faktorial. Perlakuan terdiri dari penambahan bahan pembentuk gel yaitu agar dan pati. Konsentrasi agar yang ditambahkan yaitu ( $1 \%, 2 \%$ dan 3\%) dan pati (7\%,8\% dan 9\%).

\section{Pembuatan Cassava leaf sheet}

Pembuatan produk ini dari bahan baku daun Singkong. Daun singkong dibersihkan dan dicuci dengan air mengalir untuk menghilangkan kotoran. Lalu daun singkong tersebut direbus sampai agak matang. Kemudian dihancurkan dengan menggunakan blender hingga menjadi halus. Setelah itu dilakukan pemasakan kembali untuk mencampurkan bumbu-bumbu yang terdiri dari agar, lada, garam, bawang putih dan minyak wijen. Selanjutnya dicetak dengan menggunakan loyang. Kemudian dikeringkan pada kabinet dryer suhu $50^{\circ} \mathrm{C}$ selama 18 jam. Setelah kering, cassava leaf sheet diangkat dari cetakan dan dilakukan pemotongan. Selanjutnya dilakukan analisis.

\section{Uji Kadar Air(AOAC, 2005)}

Cawan kosong yang akan digunakan dikeringkan terlebih dahulu dalam oven selama 15 menit atau sampai berat tetap, kemudian didinginkan dalam desikator selama 30 menit dan ditimbang. Sampel kira-kira sebanyak 2 gram ditimbang dan diletakkan dalam cawan kemudian dipanaskan dalam oven selama 3-4 jam pada suhu $105-110^{\circ} \mathrm{C}$. Cawan kemudian didinginkan dalam desikator dan setelah dingin ditimbang kembali.

\section{Uji Kadar Abu(AOAC,2005)}

Penentuan kadar abu dilakukan dengan metode pengabuan kering (dry ashing). Prinsip analisis ini adalah mengoksidasi semua zat organik pada suhu tinggi (sekitar $550{ }^{\circ} \mathrm{C}$ ), kemudian dilakukan penimbangan zat yang tertinggal setelah proses pembakaran tersebut. Cawan yang akan digunakan dikeringkan terlebih dahulu 30 menit atau sampai didapat berat tetap dalam oven pada suhu $100-105{ }^{\circ} \mathrm{C}$. Setelah itu didinginkan dalam desikator selama 30 menit lalu ditimbang (B1). Sampel sebanyak 5 gram dimasukkan dalam cawan yang telah diketahui beratnya, kemudian dibakar dibakar diatas bunsen atau kompor listrik sampai tidak berasap. Setelah itu dimasukkan dalam tanur pengabuan, kemudian dibakar pada suhu 400 ${ }^{\circ} \mathrm{C}$ sampai didapat abu berwarna abu-abu atau sampel beratnya tetap. Kemudian suhu tanur dinaikkan sampai $550{ }^{\circ} \mathrm{C}$ selama $12-24$ jam. Kemudian sampel didinginkan dalam desikator selama 30 menit lalu ditimbang (B2). 


\section{Uji Serat Kasar (Sudarmadji dkk, 1989)}

Sampel sebanyak $2 \mathrm{~g}$ dimasukkan ke dalam labu Erlenmeyer $500 \mathrm{ml}$ kemudian ditambahkan $200 \mathrm{ml} \mathrm{H}_{2} \mathrm{SO}_{4} \quad 0,255 \mathrm{~N}$ dan ditutup dengan pendingin balik. Didihkan selama 30 menit dan kadang kala digoyanggoyangkan. Disaring suspensi dan residu yang tertinggal didalam erlenmeyer dicuci dengan aquadest mendidih melalui kertas saring sampai air cucian tidak persifat asam (uji dengan kertas indikator $\mathrm{pH}$ ). Residu diatas kertas saring dipindahkan kembali secara kuantitatif ke dalam erlenmeyer dengan menggunakan spatula. Sisanya dicuci dengan $\mathrm{NaOH} 0,313 \mathrm{~N}$ sebanyak $200 \mathrm{ml}$ sampai semua residu masuk kedalam erlenmeyer. Dididihkan dengan pendingin balik selama 30 menit. Disaring melalui kertas saring yang telah diketahui beratnya setelah dikeringkan, sambil dicuci berturut- turut dengan larutan $\mathrm{K}_{2} \mathrm{SO} 410 \%$ aquadest mendidih, dan alkohol masing - masing sebanyak $15 \mathrm{ml}$. Kertas saring beserta isinya dikeringkan pada suhu $105^{\circ}$ Bobot sampel awal(g) kertas Berat saring Serat - $(\mathrm{g})$ kertas Berat saring $(\mathrm{g})$ kadar kasar serat $(\%)+=\mathrm{C}$ sampai berat konstan (1-2 jam). Didinginkan dalam desikator dan ditimbang dengan mengurangkan berat kertas saring yang digunakan.

\section{Uji Sensoris (Soekarto, 1990)}

Selain mempunyai sifat mutu objektif, produk pangan juga mempunyai sifat mutu subjektif yang menonjol. Sifat mutu subjektif pangan lebih umum disebut sifat organoleptik atau sifat indrawi karena penilaiannya menggunakan organ indra manusia, kadangkadang disebut juga sifat sensorik karena penilaiannya didasarkan pada rangsangan sensoris pada organ indra. Analisis sensori yang dilakukan pada penelitian ini meliputi uji skala sensori terhadap kenampakan, bau, rasa dan tekstur bakso ikan. Kisaran nilai untuk uji sensori menggunakan scoresheet adalah 1 - 5 dengan jumlah panelis 30 orang.

\section{Analisis Data}

Data dianalisis menggunakan Analisis Keragaman (ANOVA). Apabila terdapat perbedaan maka dilanjutkan uji DMRT dengan taraf kepercayaan 95\%. Analisa data dengan menggunakan bantuan software computer SPSS 21.

\section{HASIL DAN PEMBAHASAN Kadar Air}

Berdasarkan gambar (1) menunjukkan bahwa hasil analisis kadar air dengan penambahan bahan pembentuk gel agar dimana semakin tinggi penambahan agar maka semakin tinggi pula kadar air yang ada dalam produk cassava leaf sheet. Sedangkan dengan penambahan pati pada pembuatan cassava leaf sheet memiliki kadar air yang tidak konsisten. Dimana dengan penambahan konsentrasi pati 7 dan 8 kadar airnya mengalami peningkatan tetapi dengan konsentrasi 9 kadar airnya mengalami penurunan. Pada pembuatan cassava leaf sheet dengan penambahan agar memiliki kadar air rata- rata lebih rendah yaitu 10,628 sedangkan cassava leaf sheet dengan penambahan pati memiliki kadar air rata-rata sebesar 11,67. Penambahan agar pada pembuatan cassava leaf sheet dengan konsentrasi 1 dan 2 tidak berbeda nyata sedangkan dengan konsentrasi 3 berbeda nyata. Sedangkan dengan penambahan pati pada konsenrasi 7 dan 8 berbeda nyata tetapi dengan konsentrasi 8 dan 9 tidak berbeda nyata.

Kadar air rata-rata yang berbeda diakibatkan dari kemampuan mengikat air dari bahan pembentuk gel. Kemampuan menyerap air yang besar pada pati diakibatkan karena molekul pati mempunyai jumlah gugus hidroksil yang sangat besar (Winarno,1991). Penambahan air pada pati akan membentuk suatu sistem dispersi pati dengan air, karena 
pati mengandug amilosa dan amilopektin yang mengandung gugus hidroksil yang reduktif. Gugus hidroksil akan bereaksi dengan hidrogen dari air. Dalam keadaan dingin viskositas sistem dispersi pati air hanya berbeda sedikit dengan viskositas air, karena ikatan patinya masih cukup kuat sehingga air belum mampu masuk ke dalam granula pati. Setelah dipanaskan ikatan hidrogen antara amilosa dan amilopektin mulai lemah sehingga air semakin mudah terpenetrasi ke dalam susunan amilosa dan amilopektin (Meyer, 1973).

Berdasarkan hasil analisis kadar air semakin rendah kadar air maka semakin baik kualitas produk cassava leaf sheetkarena cassaava leaf sheet merupakan produk kering dan sifat yang diinginkan yaitu kering atau crispy. Produk cassava leaf sheet hasil penelitian memiliki kadar air 8,71 sampai 14,09 masih lebih rendah dibandingkan pada penelitian nori dengan bahan rumput laut jenis Glacilaria sp yaitu $15,20-17,17 \%$, produk artifisial nori bayam yaitu 7,99-10,02\%. Dimana menurut (Bhandary dan Darcy, 1996) makanan kering memiliki kadar air antara 5$25 \%$.

\section{Kadar Serat Kasar}

Kadar serat kasar Cassava leaf sheet dengan penambahan agar berbeda nyata dengan penambahan pati. Produk Cassava leaf sheet dengan menggunakan agar,memiliki rata-rata kadar serat lebih besar dibandingkan dengan produk menggunakan pati. Hal ini disebabkan karena kandungan serat pada agar lebih besar dari pati, sehingga brerpengaruh juga terhadap kadar serat kasar di produk Cassava leaf sheet.

\section{Kadar Abu}

Pengukuran kadar abu bertujuan untuk mengetahui besarnya kandungan mineral yang terdapat dalam cassava leaf sheet. Menurut Winarno et al. (1980), abu adalah zat anorganik sisa hasil pembakaran suatu bahan organik. Penentuan kadar abu berhubungan erat dengan kandungan mineral yang terdapat dalam suatu bahan kemurnian serta kebersihan suatu bahan yang dihasilkan. Abu tersebut tersusun oleh berbagai jenis mineral dengan komposisi yang beragam tergantung pada jenis dan sumber bahan pangan (Andarwulan et al., 2011). Nilai kadar abu cassava leaf sheet hasil penelitian dapat dilihat pada Gambar 3.

Hasil penelitian menunjukkan bahwa perbedaan penggunaan bahan pembentuk gel pada cassava leaf sheet mempengaruhi kadar abu pada produk. Cassava leaf sheet dengan penambahan agar memiliki kadar abu yang lebih tinggi dibandingkan dengan penambahan pati. Semakin tinggi konsentrasi yang ditambahkan maka semakin rendah kadar abu yang dihasilkan. Pada penambahan agar 1\% memiliki kadar abu yang tinggi dikarenakan agar yang ditambahkan tidak terlalu banyak mendominasi sehingga yang terdeteksi pada pengukuran kadar abu yaitu mineral dari daun singkong. Sedangkan pada penambahan pati $7 \%$ pada sampel yang diujikan kadar abu, pati terlalu mendominasi dibandingkan dengan daun singkong sehingga yang terdeteksi kandungan mineral hanya sedikit, karena kandungan daun singkong pada sampel yang diujikan hanya sedikit dibandingkan dengan pati.

\section{Uji Deskriptif}

Hasil analisis uji deskriptif dapat dilihat pada Tabel 1. Penambahan agar dan pati mempengaruhi karakteristik cassava leaf sheet terutama pada kerapuhan dan elastisitas. Semakin tinggi kadar agar dan pati yang ditambahkan maka kerapuhan dan elastitas semakin meningkat. Sampel dengan penambahan agar sebanyak 2\% menjadi sampel terbaik yang dinilai panelis, karena penambahan agar sebanyak $2 \%$ menjadi sampel yang terbaik karena sesuai dengan parameter yang kita harapkan memiliki karakteristik warna hijau agak gelap, 
aroma daun singkong tidak kuat, rasa agak gurih, rasa agak asin, agak rapuh, dan tidak elastis.

\section{Uji Hedonik}

Hasil analisis uji kesukaan dapat dilihat pada Table.2. Secara keseluruhan, panelis lebih menyukai cassava leaf sheet dengan penambahan pati sebesar $9 \%$ dengan warna yang hijau, aroma daun singkong yang agak kuat, rasa gurih, agak asin, tingkat kerapuhan dan elastisitas yang agak rapuh dan tidak elastis. Menurut Sofiah dan Achsyar (2008), uji kesukaan atau uji hedonik merupakan uji dimana panelis diminta memberi tanggapan secara pribadi tentang kesukaan atau ketidaksukaan beserta tingkatannya.

\section{KESIMPULAN}

Berdasarkan penelitian, dapat disimpulkan bahwa penambahan agar dan pati berpengaruh terhadap karakteristik kimia dan organoleptik pada produk cassava leaf sheet.Hasil penelitian didapatkan bahwa perlakuan agar $2 \%$ adalah perlakuan terbaik dengan kadar air 9, 072\%, kadar abu 33,52\%, dan kadar serat kasar yang tinggi dengan karakteristik warna hijau agak gelap, aroma daun singkong yang sedikit kuat, rasa yang agak gurih, rasa yang asin, agak rapuh, dan tidak elastis.

\section{DAFTAR PUSTAKA}

Adi, L. T. 2006. Tanaman Obat dan Jus Untuk Asam Urat dan Rematik.Penerbit PT Agromedia Pustaka. Jakarta.

Andarwulan, N.,F.Kusnandar dan D.Herawati.2011. Analisis Pangan. Jakarta. PT. Dian Rakyat. 327 hal.

AOAC. 2005. Official methods of analysis. Association of Official Analytical Chemists. Benjamin Franklin. Washington DC.

Bhandary, B.R., dan D'Arcy. 1996. Microencapsulation of Flavour Compound. Technical Review in Food. Journal of Australia Food, 48(2):547551.

Giury, M. 2006. The irish seaweed industry. http://www.seaweed.ie/Algae.html.

Diakses pada tanggal 28 Desember 2018.

Meyer, L.H., 1973. Food Chemistry. Reinhold Publishing Co Inc. New York.

Raton, F. Boca and Smooley, 1993. Everything Added to Food in the United States.

https://www.xrite.com/gellingagent.pdf (6 November 2016).

Sofiah, B. D., Achyar, T. S. (2008). Buku Ajar Kuliah Penilaian Indra. (Cetakan ke-1). Jatinangor: Universitas Padjadjaran.

Winarno et al. 1980. Pengantar Teknologi Pangan. Jakarta: PT.Gramedia

Winarno, F. G. 1991. Kimia Pangan dan Gizi Edisi 8. Penerbit PT. Gramedia. Jakarta.

Sudarmadji, S; B. Haryono dan Suhardi. (1989). Analisa Bahan Makanan dan Pertanian. Penerbit Liberty. Yogyakarta. 
Agrisaintifika

Jurnal Ilmu-Ilmu Pertanian

Vol. 3, No. 2, 2019

Maharani, dkk. 2019

Lampiran

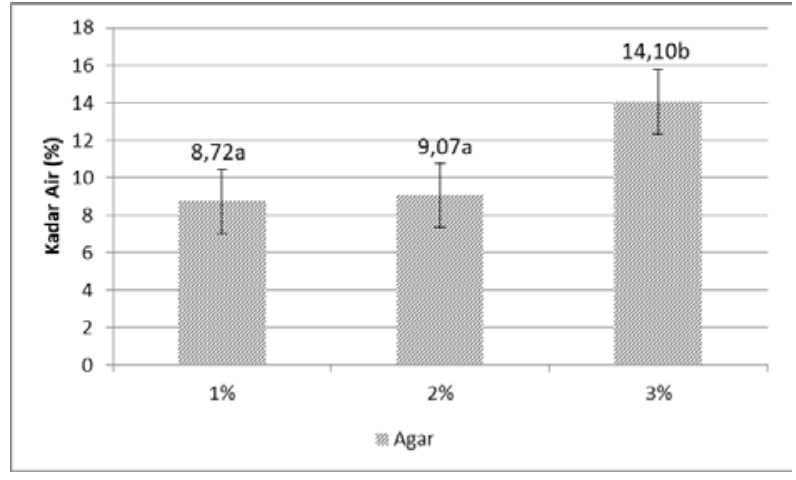

(a)

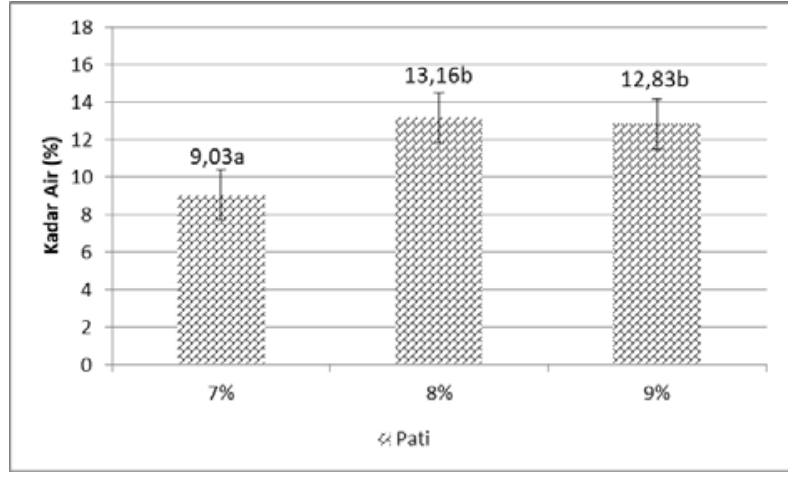

(b)

Notasi huruf kecil yang sama pada grafik menunjukkan tidak ada perbedaan nyata pada $\alpha 0,05$.

Gambar 1. Hasil analisis kadar air Cassava Leaf Sheet (a) agar, (b) pati.

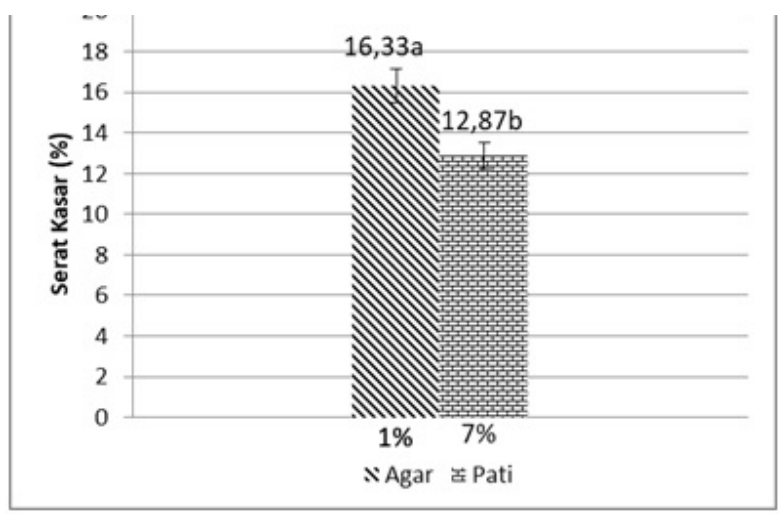

Notasi huruf kecil yang sama pada grafik menunjukkan tidak ada perbedaan nyata pada $\alpha 0,05$..

Gambar 2. Hasil analisis serat kasar Cassava Leaf Sheet

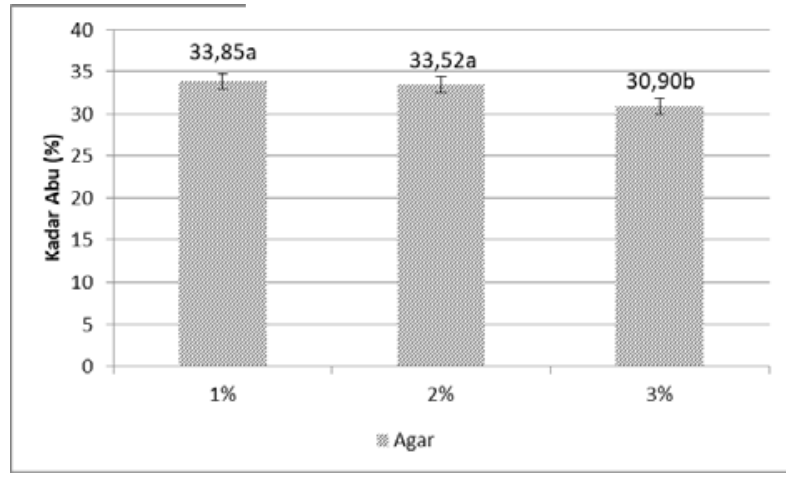

(a)

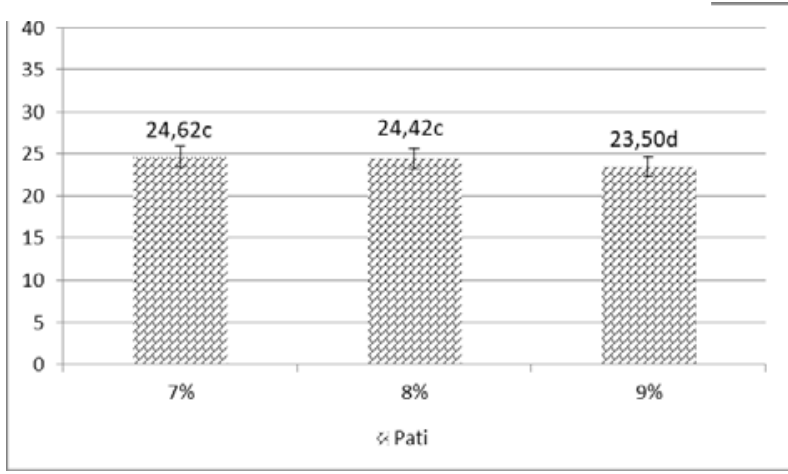

(b)

Notasi huruf kecil yang sama pada grafik menunjukkan tidak ada perbedaan nyata pada $\alpha 0,05$.

Gambar 3. Hasil analisis kadar abu Cassava Leaf Sheet (a) agar, (b) pati. 
Maharani, dkk. 2019

Tabel 1. Hasil Analisis Uji Deskriptif Cassava Leaf Sheet

\begin{tabular}{ccccccc}
\hline Perlakuan & Warna & Aroma & Rasa Gurih & Rasa Asin & Kerapuhan & Elastisitas \\
\hline A1\% & $3,63 \pm 1,15 \mathrm{a}$ & $2,86 \pm 0,97 \mathrm{a}$ & $3,63 \pm 0,76 \mathrm{a}$ & $3,83 \pm 0,79 \mathrm{a}$ & $3,30 \pm 0,95 \mathrm{a}$ & $2,46 \pm 1,04 \mathrm{a}$ \\
$\mathrm{A} 2 \%$ & $4,13 \pm 0,71 \mathrm{ab}$ & $2,56 \pm 0,77 \mathrm{a}$ & $3,46 \pm 0,81 \mathrm{a}$ & $3,73 \pm 1,02 \mathrm{a}$ & $3,13 \pm 1,25 \mathrm{a}$ & $2,26 \pm 0,82 \mathrm{a}$ \\
$\mathrm{A} \% \%$ & $3,20 \pm 1,21 \mathrm{abc}$ & $2,93 \pm 1,20 \mathrm{a}$ & $3,40 \pm 1,06 \mathrm{a}$ & $3,33 \pm 1,02 \mathrm{ab}$ & $3,30 \pm 1,08 \mathrm{a}$ & $2,60 \pm 1,22 \mathrm{a}$ \\
$\mathrm{P} \%$ & $3,46 \pm 1.25 \mathrm{abc}$ & $2,63 \pm 1,15 \mathrm{a}$ & $3,466 \pm 1,22 \mathrm{a}$ & $2,93 \pm 1,04 \mathrm{ab}$ & $3,96 \pm 0,92 \mathrm{ab}$ & $2,40 \pm 1,06 \mathrm{a}$ \\
$\mathrm{P} \%$ & $3,56 \pm 1,16 \mathrm{bc}$ & $2,633 \pm 1,15 \mathrm{a}$ & $3,40 \pm 0,81 \mathrm{a}$ & $3,33 \pm 0.92 \mathrm{~b}$ & $3,70 \pm 1,08 \mathrm{ab}$ & $2,56 \pm 1,13 \mathrm{a}$ \\
P9\% & $3,67 \pm 1,18 \mathrm{c}$ & $2,56 \pm 1,07 \mathrm{a}$ & $3,50 \pm 0,97 \mathrm{a}$ & $3,20 \pm 0,99 \mathrm{~b}$ & $3,53 \pm 1,13 \mathrm{~b}$ & $2,50 \pm 1,16 \mathrm{a}$
\end{tabular}

Notasi huruf kecil yang berbeda pada kolom yang sama menunjukkan perbedaan yang nyata pada a 0,05. Data disajikan \pm standar deviasi.

Tabel 2. Hasil Analisis Uji Hedonik Cassava Leaf Sheet

\begin{tabular}{ccccccc}
\hline Perlakuan & Warna & Aroma & Rasa Gurih & Rasa Asin & Kerapuhan & Elastisitas \\
\hline $\mathrm{A} 1 \%$ & $3,63 \pm 1,16 \mathrm{abc}$ & $2,87 \pm 0,97 \mathrm{a}$ & $3,63 \pm 0,77 \mathrm{a}$ & $3,83 \pm 0,79 \mathrm{~b}$ & $3,30 \pm 0,95 \mathrm{a}$ & $2,47 \pm 1,04 \mathrm{a}$ \\
$\mathrm{A} 2 \%$ & $4,03 \pm 0,72 \mathrm{bc}$ & $2,57 \pm 0,77 \mathrm{a}$ & $3,47 \pm 0,82 \mathrm{a}$ & $3,73 \pm 0,94 \mathrm{~b}$ & $3,13 \pm 1,25 \mathrm{a}$ & $2,30 \pm 0,88 \mathrm{a}$ \\
$\mathrm{A} 3 \%$ & $3,20 \pm 1,22 \mathrm{a}$ & $2,93 \pm 1,20 \mathrm{a}$ & $3,40 \pm 1,07 \mathrm{a}$ & $3,33 \pm 1,03 \mathrm{ab}$ & $3,30 \pm 1,09 \mathrm{a}$ & $2,60 \pm 1,22 \mathrm{a}$ \\
$\mathrm{P} 7 \%$ & $3,47 \pm 1,25 \mathrm{ab}$ & $2,63 \pm 1,16 \mathrm{a}$ & $3,47 \pm 1,22 \mathrm{a}$ & $2,93 \pm 1,05 \mathrm{a}$ & $3,97 \pm 0,93 \mathrm{~b}$ & $2,40 \pm 1,07 \mathrm{a}$ \\
$\mathrm{P} \% \%$ & $3,57 \pm 1,17 \mathrm{abc}$ & $2,63 \pm 1,16 \mathrm{a}$ & $3,40 \pm 0,81 \mathrm{a}$ & $3,33 \pm 0,92 \mathrm{ab}$ & $3,70 \pm 1,09 \mathrm{ab}$ & $2,53 \pm 1,17 \mathrm{a}$ \\
$\mathrm{P} 9 \%$ & $4,17 \pm 1,29 \mathrm{c}$ & $2,57 \pm 1,07 \mathrm{a}$ & $3,50 \pm 0,95 \mathrm{a}$ & $3,20 \pm 1,00 \mathrm{a}$ & $3,53 \pm 1,14 \mathrm{ab}$ & $2,50 \pm 1,17 \mathrm{a}$ \\
\hline
\end{tabular}

Notasi huruf kecil yang berbeda pada kolom yang sama menunjukkan perbedaan yang nyata pada a 0,05. Data disajikan \pm standar deviasi. Skor nilai kesukaan : 5 (sangat suka), 4 (suka), 3 (agak suka), 2 (tidak suka), 1 (sangat tidak suka). 